Georgetown University Law Center

Scholarship @ GEORGETOWN LAW

2001

\title{
A Vision of Health and Human Rights for the 21st Century: A Continuing Discussion with Stephen P. Marks
}

Lawrence O. Gostin

Georgetown University Law Center, gostin@law.georgetown.edu

This paper can be downloaded free of charge from:

https://scholarship.law.georgetown.edu/facpub/1811

29 J.L. Med. \& Ethics 139-140 (2001)

This open-access article is brought to you by the Georgetown Law Library. Posted with permission of the author. Follow this and additional works at: https://scholarship.law.georgetown.edu/facpub

Part of the Health Law and Policy Commons, and the Human Rights Law Commons 


\title{
A Vision of Health and Human Rights for the 21st Century: A Continuing Discussion with Stephen P. Marks
}

\author{
Lawrence O. Gostin
}

$\mathrm{P}$ rofessor Marks offers an eloquent vision of health and human rights in the 21st Century. As the Director of the François-Xavier Bagnoud Center for Health and Human Rights, Professor Marks ably carries the torch that Jonathan Mann lit in the field until his tragic death on September 2, 1998. Professor Marks stands along with the leading figures in health and human rights - e.g., Audrey Chapman, Sofia Gruskin, Michael Kirby, Daniel Tarantola, Brigit Toebes, Katarina Tomaševski, and Virginia Leary.

Perhaps Professor Marks's most notable contribution is the development, with Physicians for Human Rights, of a Declaration on Human Rights and Health Practice. Such a consensus statement would be a remarkable achievement for the field. The emphasis on "health practice," however, may emphasize health care to the detriment of public health. Preferably, a declaration on "Human Rights and Public Health" would stress the critical importance of creating the conditions for populations to be healthy - e.g., physical environment (clean air and water), built environment (livable cities and decent housing), informational environment (health education and regulation of commercial advertising), nutrition (adequate diet and safe foods), reduction in risk behaviors (safer sex and needle sharing), and elimination of health disparities based on socioeconomic status, race, and sex and gender. As a member of the Institute of Medicine's Committee on Assuring the Health of the Public in the 21st Century, we are working on this vision, which also should be central to the health and human rights agenda.

Professor Marks makes a number of helpful clarifications to my article, which was intended for a broad nonspecialist audience in human rights. I accept his suggestions with warm gratitude. I do want to engage him, and our fel-

Journal of Law, Medicine do Ethics, 29 (2001): 139-140.

(C) 2001 by the American Society of Law, Medicine \& Ethics. low scholars and activists, in a further discussion of the relationship between ethics and human rights.

In his commentary, Professor Marks argues that there exists a continuum of values with individual-level analysis at one end, where ethics is the more useful language, and societal analysis on the other, where human rights language is more useful. Professor Marks offers a visual illustration of the differences between the discourse of ethics and human rights in Figure 1 of his article. He states that Jonathan Mann felt similarly about the dichotomy between ethics and human rights. Having had the privilege of teaching and writing with Jonathan Mann, I do not necessarily believe he would have seen ethics in this highly individualistic sense. I am willing to accept that Professor Mann's writing implies such a belief, but nevertheless would like to question the wisdom or accuracy of such a position.

It is certainly true that bioethicists in the last several decades have stressed the salience of individual interests over collective goods. The ideas of autonomy, privacy, and liberty (which are central to bioethics discourse) suggest that individuals have entitlements to be relatively free of governmental intrusion. This defense of individual rights can be seen on both sides of the political spectrum: liberals prize personal freedoms, while conservatives prize economic freedoms. As a result, we live in a society that values rugged individualism and distrusts government. (Think about the public's view about taxation, regulation, as well as state bureaucracy and inefficiency.)

Given the individualistic tenor of modern bioethics discourse, it would be natural to think that ethics is principally associated with individual-level analysis. However, it was not always this way.

In writing my book, Public Health Law: Power, Duty Restraint (Milbank Memorial Fund and University of California Press, 2000), I found strong traditions of social and 
collective thought throughout American history - ideas that have been articulated by scholars such as Ronald Bayer, Dan Beauchamp, Bonnie Steinbock, William Novak, and Wendy Parmet. During most of American history (from the Founding Era to the Industrial Revolution and from the Progressive Era to the New Deal), there has been broad acceptance of the importance of a well-regulated society and the well-being of communities.

Consider Franklin Delano Roosevelt's speech in 1932, and ask whether a modern politician would express these ideas today:

The success or failure of any government in the final analysis must be measured by the well-being of its citizens. Nothing can be more important to a state than its public health; the state's paramount concern should be the health of its people.

The United States is now re-capturing the lost tradition of public health ethics. The Hastings Center (lead by Daniel Callahan and Bruce Jennings) is engaging in a project on public health ethics; the Association of Schools of Public Health is developing model curricula on the subject; and the Public Health Leadership Society is drafting a code of public health ethics. These and other initiatives are founded on the idea that ethics can illuminate the values of mutual responsibility, solidarity, and community. Rather than seeing ethics as serving principally individual interests, these groups perceive ethics as demonstrating the importance of common goods notably, the benefits of living in a society that appreciates health, safety, and well-being in populations. I therefore believe that ethics is not inherently allied to medicine and indi- vidualism, but can articulate the meaning and salience of public health.

Professor Marks sees human rights as most helpful language in defending a societal perspective. He therefore prefers human rights, rather than ethics, discourse to promote the public's health. I understand the power of human rights in pursuing the goal of healthy communities, particularly the collective rights found principally in the International Covenant on Economic, Social, and Cultural Rights - e.g., the right to health, the right to education, and the right to share in the benefits of scientific and technological progress. But the field of human rights, like ethics, has an equally strong individualistic tradition that stresses free expression, association, privacy, and liberty. Even in the health context, human rights often has focused on medicine and de-emphasized public health. For many, the right to health has meant, almost exclusively, an entitlement to personal medical care.

Professor Marks might agree that neither ethics nor human rights can lay claim to be the exclusive mode of thinking to further the goal of population well-being. Modern ethics and human rights have dwelled on the rights of individuals and often failed to articulate a clear vision to assure the conditions for healthier and safer communities. There is, however, a strong collective and egalitarian tradition in both fields. Ethical analysis can help explain why individuals should forego some of their liberties and entitlements to benefit from living in a secure and wholesome society. Human rights analysis can flesh out the meaning of social, economic, and cultural rights and provide better enforcement mechanisms. That, I think, is Jonathan Mann's legacy and it is one that the FXB Center and our colleagues around the world can ably pursue in the 21 st Century. 